\title{
Effectiveness of governance towards digitalisation at eThekwini Metropolitan Municipality in KwaZulu-Natal province, South Africa
}

\begin{tabular}{|c|c|}
\hline \multicolumn{2}{|c|}{$\begin{array}{l}\text { Authors: } \\
\text { Nirmala Govender }{ }^{1} \text { ( } \\
\text { Purshottama S. Reddy }\end{array}$} \\
\hline \multicolumn{2}{|c|}{$\begin{array}{l}\text { Affiliations: } \\
\text { 'School of Management, } \\
\text { Information Technology and } \\
\text { Governance, College of Law } \\
\text { and Management Studies, } \\
\text { University of KwaZulu-Natal, } \\
\text { Durban, South Africa }\end{array}$} \\
\hline \multicolumn{2}{|c|}{$\begin{array}{l}\text { Corresponding author: } \\
\text { Nirmala Govender, } \\
\text { nirmala.govender@durban. } \\
\text { gov.za }\end{array}$} \\
\hline \multicolumn{2}{|c|}{$\begin{array}{l}\text { Dates: } \\
\text { Received: } 28 \text { June } 2019 \\
\text { Accepted: } 18 \text { Sept. } 2019 \\
\text { Published: } 09 \text { Dec. } 2019\end{array}$} \\
\hline \multicolumn{2}{|c|}{$\begin{array}{l}\text { How to cite this article: } \\
\text { Govender, N. \& Reddy, P.S., } \\
\text { 2019, 'Effectiveness of } \\
\text { governance towards } \\
\text { digitalisation at eThekwini } \\
\text { Metropolitan Municipality } \\
\text { in KwaZulu-Natal province, } \\
\text { South Africa', Africa's Public } \\
\text { Service Delivery and } \\
\text { Performance Review 7(1), } \\
\text { a336. https://doi.org/ } \\
\text { 10.4102/apsdpr.v7i1.336 }\end{array}$} \\
\hline \multicolumn{2}{|c|}{$\begin{array}{l}\text { Copyright: } \\
\text { (c) 2019. The Authors. } \\
\text { Licensee: AOSIS. This } \\
\text { is licensed under the } \\
\text { Creative Commons } \\
\text { Attribution License. }\end{array}$} \\
\hline \multicolumn{2}{|l|}{ Read online: } \\
\hline 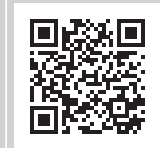 & $\begin{array}{l}\text { Scan this QR } \\
\text { code with your } \\
\text { smart phone or } \\
\text { mobile device } \\
\text { to read online. }\end{array}$ \\
\hline
\end{tabular}

Background: South African cities have been facing challenges since democratisation to meet the expectations of the citizens. The challenges have included fraud and corruption, financial constraints, lack of service delivery and technological progress, amongst others, which were underpinned by weak leadership and governance processes. This article explored eThekwini Metropolitan Municipality's technological progress and identified that inefficiencies in good governance and the lack of a governance framework have limited digitalisation.

Aim: The aim of this study was to assess the progress towards digitalisation and review the effectiveness of the governance processes within the eThekwini Municipality in contributing towards the fourth industrial revolution.

Setting: The study was based on the processes at the eThekwini Municipality in KwaZulu-Natal province, South Africa.

Methods: A qualitative research approach was used, and the study is exploratory in nature.

Results: The study identified that there was limited digitalisation at eThekwini Municipality. Furthermore, governance processes and an overall governance framework were lacking within the municipality. There was also limited support from the national government to address the fourth industrial revolution at local government level.

Conclusion: The implications of a lack of a strong public governance framework, and not being supported sufficiently by the national government, mean that the eThekwini Metropolitan Municipality cannot compete internationally within the digital economy. The national government must co-ordinate a collaborated effort towards digitalisation, especially at municipal level. A multilevel governance framework, identifying collaboration between the various levels of government and the public, has been identified as the key response in embracing and enhancing the fourth industrial revolution within municipalities.

Keywords: municipal governance; corporate governance; multilevel governance; fourth industrial revolution; technology; eThekwini Municipality.

\section{Introduction}

Cities are the epicentre of technological advancement, and the advent of the fourth industrial revolution through digitalisation can either stimulate growth or impede the progress of local government operations. According to Schwab (2016), the fourth industrial revolution is considered to be the synthesis of various technologies involving digital, physical and biological domains. O'Callaghan (2018) contends that the fourth industrial revolution will essentially transform society and the economy. In 2018, the World Economic Forum (WEF) clarified that the dynamic changing force of the fourth industrial revolution necessitates a new form of governance to be in place, to address and oversee the interwoven complexities and impact of emerging technologies (WEF 2018:5).

Therefore, the WEF advocates for a new governance framework to address the manner in which the transformation of technologies, especially related to new corporate and personal opportunities created, impact on policy decision-making (WEF 2016:1). Furthermore, a new governance framework is required to ensure the efficient administration of government services to citizens (WEF 2016:1). The WEF recommends that governance must move from a traditional rule-based compliance to an 'outcome-orientated approach' which can respond to the technological transformation (WEF 2016:2). 
According to the WEF, public governance has been the responsibility of governments, through the formation of legislation or 'executive acts'; however, governance needs to be agile in dealing with the rapid pace of development andevolving technological advancements (WEF 2018:6). According to Jagannath University, corporate governance refers to a company's rules or instructions and best practices which allow the achievement of a company's goals, whilst public governance is the 'exercise of public authority by state governments aimed at generating rules and regulations and delivering services to a community of citizens' (Jagannath University 2019). The efficacy of public governance, consequently, is also impacted by rapid technological advancements, which will have an impact not only on how services will be delivered but also on the human resource skills which will be required to engage with new technologies. West (2018) contends that the fourth industrial revolution could potentially 'disrupt' every global industry, through 'large-scale automation, adoption of emergent technologies, big data and artificial intelligence', and change the jobs and skills required. Another concept which has emerged within the context of the fourth industrial revolution is digitalisation, which is regarded as the 'digital transformation of society and the economy', and which will generate challenges for government organisations and educational institutions amongst others (Innolytics 2019). This research paper was therefore relevant as it reviewed eThekwini Municipality's progress towards digitalisation and assessed the effectiveness of governance processes at the eThekwini Metropolitan Municipality in the radically changing technological era of the fourth industrial revolution. For the purpose of this research study, public governance is the main focus; however, King IV uses the term 'corporate governance at local government level' as a reference to municipal or public governance. Therefore, the term 'public governance' or 'municipal governance' within the local government context is used interchangeably with 'corporate governance', when referring to King IV.

The fourth industrial revolution, also known as the digital industrial revolution (DIR) or Industry 4.0 (McGinnis 2018), is a reality that is changing the world which has been a topical area of recent times. However, this article aimed to explore the progress of the fourth industrial revolution in relation to the governance processes within local governments, which has not been explored extensively.

This study therefore focused on municipal governance within the context of the fourth industrial revolution at the eThekwini Metropolitan Municipality, which has been categorised by the Municipal Demarcation Board (MDB) as a 'Category A' metropolitan municipality, as it is 'governed by single councils with exclusive executive and legislative authority within their boundaries' (Municipal Demarcation Board 2017:8). The eThekwini Municipality spans an area of $2555 \mathrm{~km}^{2}$ in the KwaZulu-Natal province of South Africa and is a leading city in the province (eThekwini Municipality 2018b:31). The Integrated Development Plan (IDP) (City of
Cape Town 2017) of the municipality indicates that the gross domestic product (GDP) growth rate of the city was slowing down; as in 2016, it was 1.00\% and was 1.03\% in 2017 and grew at $0.90 \%$ in 2019 . However, this pattern is the forecast for the entire country. The municipality has a population of approximately 3.4 million according to the 2011 Census (eThekwini Municipality 2018a). Of concern for the municipality, however, is that the population is growing more rapidly than the economy (eThekwini Municipality 2018c:109-110).

The aim of this study was to explore eThekwini Municipality's response to digitalisation and assess the effectiveness of the governance framework within the eThekwini Municipality in relation to the fourth industrial revolution. This article provides an overview of the research methods and design used in this study; the literature review then follows with the implications of the fourth industrial revolution on municipalities; the theoretical frameworks underpinning the study; an overview of South Africa in the digital revolution; the results of the study; a discussion on the results; and the conclusion.

\section{Research methods and design}

The research method followed a qualitative approach to explore eThekwini Municipality's response to digital technology and to assess the effectiveness of the governance processes and governance framework at the eThekwini Municipality in embracing the fourth industrial revolution. Bacon-Shone (2015:40) states that the qualitative method is perhaps more involved with the circumstances of the situation rather than the statistics, and this provides a rich perspective, which is difficult to attain with quantitative procedures. Furthermore, the methodological inquiry process adopted in exploring a problem in a qualitative study provides the formulation of a multifaceted, holistic view, with an analysis of words detailing the understanding of the participants in their natural situation (Bacon-Shone 2015:41). Unique information is collated by the researcher through a qualitative approach (Daniel 2016:93) and a factual descriptive view of the situation is provided (Johnson \& Christensen 2012, as cited in Daniel 2016:93). Qualitative research has been identified as critical to this study, as it offers the perspective of the various stakeholders within the municipality, using the technique of semi-structure interviews. Bryman (2012:557) states that content analysis allows the researcher to use themes to search in the documents being analysed. Content analysis was used to analyse the content of legal and municipal documents as well as national reports.

The eThekwini Municipality was chosen as the location, as it is one of the eight metropolitan municipalities in South Africa and provides a range of services to the public. The research design uses a qualitative methodology, which entails the collation of data from interviews with councillors and management, and the secondary analysis of documentation obtained from the municipality. Sources of data therefore included the responses from interviews, municipal data and legislation, information from professional institutions, 
website articles, government published data, media articles and academic literature, including academic journal articles and papers.

Firstly, this study reviewed eThekwini Municipality's progress in digitalising critical processes and also provided a view of the eThekwini Metropolitan Municipality's governance responsiveness to the digital era. Secondly, as the study dealt with digitalisation and the effectiveness of governance processes in contributing towards the fourth industrial revolution, it was appropriate to obtain the views of the councillors, representing the political governance component of leadership, and management who represented the administrative governance component of leadership. Semistructured interviews allowed the respondents to provide a complete and unfettered response to the questions posed on the effectiveness of governance within the eThekwini Municipality.

Although the full council comprises of 219 councillors, representing the various political parties elected in 2016 (eThekwini Municipality 2018b:50), the study population chosen for councillors consisted of twenty-four councillors from both the Executive Committee of Council (EXCO) and the Municipal Public Accounts Committee (MPAC) members. EXCO recommends overall decisions to Council for approval, whilst MPAC undertakes an oversight role for Council. Both the EXCO and MPAC are based on political party representation at municipal council (eThekwini Municipality 2018b:48-49). Certain EXCO members were also chairpersons of sub-committees of council where oversight of decisions was also undertaken. The sampling strategy used was judgemental sampling of councillors based on the responsibilities within the committees. Sub-committee and MPAC members including representation from opposition parties were chosen. The sample size was $33 \%$ of the population, which amounted to a total of eight councillors. In-depth, semi-structured interviews were also undertaken with $10 \%$ of eThekwini Municipality senior managers. The population for management was 154 senior managers of the municipality with a sample size of 16 senior managers. The senior managers were chosen using judgemental sampling from a cross-section of the municipality.

Primary data were obtained from interviews with the respondents. Interview questionnaires were compiled and tested prior to undertaking the interviews. Data were collected through either typing or writing down the responses and most interviews were permitted to be audio recorded. All respondents were comfortable to respond in English and did not require an interpreter. Respondents were informed that there was no risk involved in undertaking the interviews, which could be stopped at any time if so required. Audio recordings were converted electronically, whilst manually recorded interviews were captured onto MS Word. Responses were reviewed and coded according to content analysis and the major themes identified for the article were processed using the NVIVO software.
Ethical considerations were monitored and adhered throughout the research process. Bryman (2012:130) states that ethical matters occur throughout various periods during research, and cannot be overlooked, due to issues of integrity. The ethical principles and guidelines of the University of KwaZulu-Natal were adhered to, both implicitly and explicitly, in terms of ethical clearance. Written permission was obtained from the eThekwini Municipality to source research data. All information collated was maintained in a safe location and was treated as confidential. Informed consent forms were completed by all respondents, ensuring voluntary and informed participation. Anonymity and confidentiality were ensured by not directly referring to the respondents in the questions, and privacy was ensured by undertaking the interviews in closed offices and not disclosing the names of the respondents in the study. Findings were reported in an unbiased and honest manner and without any misrepresentations.

\section{Literature review}

\section{Implications of the fourth industrial revolution on municipalities}

The WEF contends that the developments brought about by the fourth industrial revolution results in both risks and opportunities (WEF 2017:22). Harvey (2017) contends that the momentum of new technologies emerging is expected to have a massive impact globally. Innovative technologies have more speed, are more connected, are easily available to the population and are more efficient, as there is 'a merging of digital, physical, biological realms' (Price Waterhouse Coopers 2018:1). Business models will have to be reconfigured to embrace technologies of artificial intelligence, 3D printing, remote sensing and satellite imagery, and vertical farms, amongst others (Harvey 2017). Therefore, it is quite apparent that, in this decade, technologies are becoming redundant more quickly than anticipated as a result of the continuous advent or creation of new advanced technologies.

The United Nations has established that although the global demand for 'high-speed fixed broadband' is increasing, access is mostly unavailable to populations in developing countries, with only $6 \%$ of residents having access, whilst $24 \%$ have access in developed areas. Furthermore, this only widens the prevailing inequalities. Access to fixed broadband provides opportunities for international arrangements, increase in access to innovation, science and technology and knowledge sharing (UN 2018:30). Harvey (2017) reasons that the adoption of a 'smart grid' will provide the opportunity to distribute electricity to many households in isolated areas, allowing access to light at night for children studying, for meals to be prepared on safe cookers and air pollution indoors being eliminated.

From a municipal perspective, Copping et al. (2018:7) argue that innovative city administrators will have to focus on new technologies to make 'cities smart', by focusing on accessing data which is timeous and reliable and to solving challenges almost immediately, for example, refuse collection and 
emergency services. Furthermore, this could improve service delivery and ensure informed decision-making. The fourth industrial revolution also provides solutions for waste management, as technologies for waste segregation are quicker and easier using robots. However, Roberge (2018:9) is of the opinion that although governments could be pressurised into delivering more services through 'robotisation', this may lead to a decrease in employment opportunities. Roberge (2018:9) states further that if the government does not manage the fourth industrial revolution, critical economic, social and political upheavals will occur.

Harvey (2017) argues that risks are associated with any revolution, and joblessness is the risk involved with the fourth industrial revolution. The WEF confirms that many routine white-collar jobs will become redundant by 2022 (WEF 2018:9). The fourth industrial revolution also brings with it the risk of loss of many jobs that require manual labour or are clerical in nature (Tshabalala 2019). The rate of unemployment is currently extremely high, mostly impacting the youth, and South Africa is not fully utilising the vigour and talents of the youth effectively (Tshabalala 2019). Much of the skills and knowledge gained by previous generations are also redundant in the new age. Butler (2018) states that education needs to be remodelled to be suitable for the new generation, and furthermore, that the skills and knowledge capacity of more than half of the labour force needs to be re-engineered. Therefore, West (2018) states that approximately 65\% of the jobs of the future are not yet known and essential capabilities of people must be invested in, instead of conventional training. Furthermore, 'resilient leadership' is required to be invested in, which is not associated with any focused job, so that skills can become transferable (West 2018). Governments therefore need to determine how the labour component will react to transformed policies on education and skills to address new technologies (WEF 2017:22). Local governments will be highly affected by changes in education and skills requirements and potentially unemployment, as it is the government closest to the people, and has the most contact with communities.

\section{Theoretical frameworks underpinning the study}

Municipal governance relates to governance within a municipal environment or local government context (Taylor 2016:2-3). Reddy (2016:1) states that local government is critical as it is the governance that is 'closest to the people'. Furthermore, Reddy (2016:4) points out that local government can be regarded as the 'engine of local development' and is primarily responsible for the delivery of basic services. To support these assertions, the New Public Management (NPM) approach and the King IV corporate governance framework are explored in relation to the research study.

New Public Management identifies various styles of public management and administration, which occurred in the 1980s, in the various countries which were members of the Organisation for Economic Co-operation and Development (OECD) (Robinson 2015:4-7). Robinson (2015:7-9) argues that various criticisms of NPM have resulted in other iterations emerging, including the New Public Governance (NPG) approach, whilst still under the banner of NPM.

Robinson (2015:9) indicates that the NPG has citizens as the centre of focus instead of government, and there are several different approaches that make up NPG, and the 'New Public Service' (NPS) is one of these approaches. With the focus of the NPS approach being on citizens as one of the criteria and on multiple contributors towards the organisations' goals as the other it is ideally one of the most appropriate approaches for local governments. According to Robinson (2015:10), the NPS articulates that 'citizens, community and civil society' are the ideal focus for public management. Furthermore, Denhardt and Denhardt (2007:139) argue that within this context, the role of government employees is to ensure the welfare of citizens according to their needs, rather than to provide a top-down approach.

Robinson (2015:15) has confirmed that a 'whole-ofgovernment' approach will address issues of disjointedness and disintegration with the NPM Method, and that digital municipal governance provides the opportunity to ensure efficacy and transparency consecutively. Ratifying this by reflecting on previous studies, Heeks and Bailur (2007:8) identify that information technology impacts positively on service delivery. Yildiz (cited in Robinson 2015:11) also confirms that previous literature on governance in a digital environment concentrated on efficacies in service delivery, which are achieved through technology.

Various other approaches as referred to by Robinson (2015:11) are the 'whole of government approach, digital governance, and motivation to redress the problems of organisational coherence and responsiveness associated with $\mathrm{NPM}^{\prime}$ ', which focuses on citizen welfare and 'public sector ethos'. Dunleavy et al. (cited in Robinson 2015:11) indicate that various analysts have identified the prospect of 'new digital technologies' transforming government's relationship and business transactions with civil society. Osborne, Radnor and Nasi (2013:150) offer an overview of various research opinions on digital governance, which essentially indicates that digital governance has the potential to re-energise a participatory approach to public services increasing the public's participation in service delivery. However, Mbecke (2014:101) argues that corporate governance has not been given due consideration in developing countries. According to Mulili and Wong (as cited in Mbecke 2014:101), more complex solutions are required to address the challenges experienced in developing countries.

A review of the King Code of Corporate Governance, up to the second iteration, did not reflect any reference to local governments. In 2010, deliberations regarding King III and governance in local governments took place (PWC \& IODSA 2010:1). However, King III does not explicitly provide a code of governance for local governments, although it recommends implementation at local government level. In 2016, with the 
introduction of King IV, an explicit code of corporate governance for local governments was established, which specifically included standards for corporate governance at local government level (IODSA 2016). Furthermore, information and technology are now criteria in the King Code of Good Governance. However, King IV, like all other King codes, contains voluntary governance principles and practices, and recommends only the best practices to implement (IODSA 2016:35). Nevertheless, many private organisations have adopted many of the King principles; however, even with the major challenges experienced by local governments regarding governance, there has been no initiative to implement the recommended governance frameworks at municipal level, which are intended to improve governance.

\section{An overview of South Africa in the digital era}

The Government of South Africa has identified that the fourth industrial revolution will have huge implications on the economy of South Africa. In January 2019, the South African Minister of Finance indicated that the country needs to prepare itself for the fourth industrial revolution and that the budget will include issues such as overhauling previously underprivileged schools and investment in digital and technological skills (Van der Merwe 2019).

In order to facilitate a plan of action, Government has established a commission to organise a 'national response action plan to deal with the fourth industrial revolution' (Republic of South Africa [RSA] 2018b:5). The President of South Africa has indicated that:

'Our prosperity as a nation depends on our ability to take full advantage of rapid technological change. This means that we urgently need to develop our capabilities in the areas of science, technology and innovation.' (RSA 2018b:10)

The South African government must ensure the development of a national data policy in order to enable the delivery of 'digitally-enabled services' to the population, as well as provide digital content to users (RSA 2018b:10). Furthermore, government departments will have to transform the way public participation and policy development is undertaken and will also have to adapt to the pace of change by reinventing themselves (RSA 2018b:15-16). Collaboration with civil society and business is important for the success of the emerging digital economy, and citizens will be able to engage and express their opinions through new digital platforms (RSA 2018b:15-16).

From the perspective of attracting investors into cities, South African cities have much to accomplish in terms of digitalisation. The World Bank's (sub-national) 'Doing Business (SNDB) in South Africa' report has identified a number of critical issues for the metropolitan municipalities, including the eThekwini Municipality, in terms of the efficiencies of doing business within the Municipality. The main areas which are focused on in the SNDB assessment are efficacies of construction permits, getting electricity and registering property (World Bank 2018:iii). One of the findings identified in the study revealed that many municipalities use a manual paper-based method to control construction permit applications, and only a handful of municipalities have begun the digital revolution process. The City of Cape Town is the only metropolitan municipality that uses an electronic system, and although eThekwini Municipality is one of the other metropolitan municipalities which expressed interest in moving towards an electronic platform, it will require commitment, cost-benefit analysis and further exchanges to be implemented (World Bank 2018:35).

Another finding by the World Bank is that non-technical electricity losses have a massive economic impact on cities. Non-technical electricity losses occur as a result of vandalism, illegal connections, cable theft and errors in accounting. To address the issue of losses, only three metropolitan municipalities have been gradually implementing smart grid technologies (World Bank 2018:49). The eThekwini Municipality has been identified as one of the municipalities that has not yet been able to move towards digital transformation in the case of electricity.

The World Bank has stated that for registering property 'the gold standard is a fully digital, unified or linked property registry and cadastral mapping system that allows staff to electronically search and update records' (World Bank 2018:59). However, although many of the metropolitan municipalities in South Africa, including the eThekwini Municipality, have moved technologically to online clearance certificates and electronic billing systems, certain processes are backlogged as a result of system failures, slow migration of data, implementation delays and lack of staff training. eThekwini Municipality has been identified as having challenges with substantial backlogs, as systems were dysfunctional for a number of weeks for the migration of data (World Bank 2018:63).

The World Bank's study makes it clear that each metropolitan municipality in South Africa is at a different stage of the fourth industrial revolution (World Bank 2018:54-67). Furthermore, there is no synchronised effort to ensure that all municipalities develop digitally.

Mzekandaba (2018:14) argues that the main reason preventing the institutionalisation of e-government plans in South Africa is the inconsistent implementation of technology development at municipalities and other government departments. There are disparate systems, limiting the potential to converge and align systems, and limited budget for expensive technologies. According to Holdsworth (2018:17-19), transformative initiatives, in particular e-government, takes a longer period to be implemented and mature, as it requires a complete overhaul of government infrastructure, workforce, processes and systems.

Therefore, leadership and governance processes are critical for South Africa to prepare itself for the fourth industrial revolution as a country. Furthermore, Aranguren (2018:2) 
indicates that if progress is not made towards the creation of a different model for governance, which include various role-players and not just government, obstacles could arise hampering entrepreneurship and effective and efficient growth and development in smart strategies.

Copping et al. (2018:7) identify that the gap that exists at municipal level is that city administrations are not fully equipped to exploit or take advantage of digitalisation and technologies. Copping et al. (2018:8) contend that 'horizontal thinking' and 'integrated planning', as well as moving beyond silos, are required to 'reimagine existing systems, create new processes and interactions, and migrate towards new forms of service delivery'.

\section{Results}

The study revealed various findings that hamper the growth of the eThekwini Municipality in progressing technologically.

\section{Effectiveness of governance processes}

The Department of Planning, Monitoring and Evaluation (DPME), in its 20-year review of local governments in South Africa, has identified many challenges related to governance since democratisation, which are: (1) 'the lack of political leadership'; (2) cases of 'political interference' and (3) 'patronage' (RSA 2014:10). Other local government challenges identified by the DPME are the lack of coherent policies, complex reporting demands and a large number of municipalities having weak institutional abilities (RSA 2014:10). The DPME also identified that the problems experienced by 'local governments' include inefficient and ineffective municipal administration, condoning political interference, poor leadership (administration and political), weak compliance, the inability of 'local governments' to respond to the complex demands and expectation of the citizens, a declining skills base to deal with socio-economic legacies and service delivery failures (RSA 2014:10). From the 20-year review provided by DPME, it is clear that governance at municipalities is jeopardised, which in turn affects service delivery to the masses.

In order to establish the views of management and councillors within eThekwini Municipality on the effectiveness of governance processes, questions for this study were extracted from a doctoral research study, which included questions to both management and councillor of the eThekwini Municipality. The question identified for this article was whether the respondent believed that there were effective governance processes place at eThekwini Municipality to ensure a well-maintained city in line with the vision to be the most caring and liveable city by 2030 .

The responses from the semi-structured interviews with management and councillors provided sufficient feedback on whether governance was effective within the municipality. One of the respondents to the interviews about the effectiveness of the governance processes within eThekwini Municipality indicated that:

'I think there are governance processes, but whether they are effective, that's another issue. I think we've got enough governance processes, and now we just need the political will, and we need people to be willing to take action.' (Respondent C4, female, councillor)

Agreeing with this opinion, another respondent indicated that:

'Well, there might be effective governance processes in place, but sometimes being disturbed by political interference. It's very difficult sometimes for the officials to do their work properly if the politicians will somehow, somewhere interfere. So, while the officials may want to put their hundred percent, they might be disturbed along the way.' (Respondent C3, male, councillor)

Respondents also deliberated over issues of leadership and governance and one respondent indicated:

'It's all about the issue of governance. The governance systems are not effective; or I would say the governance systems in Africa are self-serving. The systems that are put in place might be okay, but it is the governing behaviour in Africa or African leadership that is self-serving. This gives birth to poverty, frustrations and lack of jobs; and inwardly, the people have a resentment of the government's governance systems. They will then end up doing things that are contrary to the government. So, it's all around the governance behaviour. And enforcement systems are also compromised, by unknown social contracts that exists between those in power and some ordinary people.' (Respondent M1, male, senior management)

Issues of politics were also highlighted as a concern by respondents:

'Well, there is some level of participation, especially at the ward level, where Councillors are participating. But my challenge is, is the participation with an objective of getting more votes rather participation of changing this scenario?' (Respondent M1, male, senior management)

A Manager responds that the city's challenges are in the hands of the leadership:

'But our Educational initiatives are lacking, and you need strong leadership to go through the right channels and some of these things need to be repeated by Political parties.' (Respondent M2, male, senior management)

This is corroborated by a respondent to the study as to whether the governance processes were effective:

'The eThekwini Municipality is not effective in governance processes.' (Respondent C2, female, councillor)

Analysis of the governance section in both the IDP and the Annual Report of the municipality identified that no reference is made to information, technology or digitalisation. However, the IDP indicates that there are 'systems in place to ensure accountability, efficiency and effectiveness of the Municipality' (eThekwini Municipality 2018c:252). The systems referred to in the IDP include community and stakeholder engagements, 
community-based planning, ward committees, Operation Sukuma Sakhe - a provincial programme of the government to reach the people - communication, customer relations management, audit and risk management, business continuity management, anti-fraud strategy and performance monitoring and evaluation (eThekwini Municipality 2018c:252-256).

The gap identified in the governance processes at the eThekwini Metropolitan Municipality is the lack of integration of technology into the IDP and the Annual Report of the Municipality.

\section{IT Governance Framework}

In June 2015, the eThekwini Municipality approved the Corporate Governance of Information and Communication Technology (CGICT) Policy and Framework, which was based on the Department of Public Service and Administration (DPSA) framework. The CGICT Policy and Framework was approved in order to ensure accountability and responsibility for Information and Communication Technology (ICT) decision-making as well as monitoring ICT performance and conformance to policies and legislation (eThekwini Municipality 2015:1). One of the purposes of the framework was to 'embed the CGICT within corporate governance in eThekwini Municipality' (eThekwini Municipality 2015:2). However, the challenge is that the eThekwini Municipality does not have an overall corporate governance framework, which then causes confusion when implementing the CGICT.

The study indicates that there are sufficient processes over internal controls and accountability for information and technology, as well as support by councillors and management for a technological revolution as indicated below:

'So, if we're going to get technology, let's get technology that works and it's available.' (Respondent C1, male, councillor)

Technological tools over the years have increased the efficiency within local government organisations from word processing applications to financial software. Therefore, enhancing the use of technology will definitely improve municipal organisations in delivering services. A respondent expounded on the benefits of using technology:

'So, if you have technology and it's available, why aren't you using it? Because ultimately the initial outlay may be slightly higher than we expect to pay but the long-term benefits are huge. You know if we can get technology and it is available for you to use it in any field, any other projects that are taking place in the community with it means, that we are more effective.' (Respondent C1, male, councillor)

Although there is support for technological advances, the municipality has not been able to advance in the digital field.

\section{Huge investment in disparate and ineffective technological systems}

Each level of government, as well as different departments within each institution, has several varying technological systems, and many systems are still being developed in a silo manner at each institution. Huge investments at various government departments result in limited funding for basic service delivery. At eThekwini Municipality, the Revenue Management System (RMS) has taken many years to develop; however, there are ongoing issues in the departments within the Municipality challenging the efficacy of the system, as well as the public being unhappy with incorrect billing. The eThekwini Municipality has spent approximately R1 billion on implementing the RMS, which is a billing system intended to cut costs. However, it has been established that a further R1.5 million a month is being paid to consultants to maintain the system (Shaikh 2018). According to Ndaliso (2019), the system has created confusion within the electricity unit as it is not able to track and monitor expenditure. Moreover, an official from the municipality indicates that the system is malfunctioning (Ndaliso 2019). This reflects the vast funding set aside for electronic systems, which is apparently not performing.

\section{The national government plan for the fourth industrial revolution}

The Government of South Africa has identified the need to roll out processes and strategies to address the potential of the fourth industrial revolution (RSA 2018a). However, of concern is the lack of focus at a municipal level. The national government is relinquishing its responsibilities, and municipalities have no choice but to develop processes at local levels to deal with the potential of digitalisation.

\section{Lack of intergovernmental efforts to develop municipal systems}

Each municipal environment is developing its own digital platforms, resulting in economies of scale being lost through these endeavours, and municipalities are currently operating in a competitive environment within South Africa. This is a risk, as municipalities have limited financial funding. Each level of government, as well as each entity within the three levels of government, is embarking on technological efforts towards the fourth industrial revolution. Huge sums of funding are spent on developing systems and by working collaboratively, huge savings can be achieved. The governance framework identified in this study seems to be the ideal response in dealing with the fourth industrial revolution; however, with substantial investment required at municipal level, not much will be accomplished unless joint endeavours are pursued.

\section{Discussion}

The key findings from this study are that, firstly, although the eThekwini Municipality is bound by the legislative requirements, this is not sufficient in addressing all the components of public governance. Secondly, massive investments have been made to deliver technology which is cumbersome and is creating more challenges for the Municipality. Thirdly, the national plan to address the fourth industrial revolution by the South African government must incorporate the inputs and responses from municipalities, as this is the level of government which is at the coal-face 
of the communities. Furthermore, collaborative efforts to advance into the fourth industrial revolution must be undertaken between the various levels of government. For the success of an endeavour that will move the country forward towards the fourth industrial revolution, local governments are the key respondents.

The ideal panacea will be a multi-governance approach, which will ensure the participation of civil society, academia, business and governmental organisations at all levels, and ensure multiple funding sources and multitude of growth and development opportunities. This will provide South African Municipalities an opportunity to be successful in its endeavours to harness the potential of the fourth industrial revolution, not only for the benefit of the State but also for the citizens of the country.

\section{Multi-governance as an option for government}

In 2014, the Council on Digital Government Strategies for the OECD recommended digital strategies for government (Organisation for Economic Co-operation and Development [OECD] 2016:41). The strategies stated that in order to preserve public trust as well as commit to trustworthy leadership and political commitment to the strategy, citizens must be engaged in the design and delivery of public services, as well as in a transparent, open and inclusive manner on policy development (OECD 2016:41).

The Commission on Global Governance further clarifies that global governance is an ongoing process whereby differing or varied interests could be accommodated, and supportive responses are undertaken (Lamb 1995:2-3). Price (2018) states that the key features of good governance are that they should display 'participation, consensus ... accountability, transparency ... [and strategic vision]'. They should be 'responsive, effective and efficient, equitable and inclusive' and should 'follow the rule of law'.

For digital initiatives to be successful, support is required from national and subnational political leadership, and from integration and coordination between various levels of government (OECD 2016:41). This type of multilevel effort will ensure that strategies developed for digitalisation will benefit various levels of government and entities through joint financing and commitment and shared ownership (OECD 2016:41). This will work well within the South African context, as it will move away from a silo approach within government, bringing in alignment, effectiveness, efficiencies and true intergovernmental relations in the process.

\section{Conclusion}

It is apparent that public service organisations have not been able to harness fully the capabilities of digitalisation and have introduced technology which is only operational and is not strategic in function (Osborne et al. 2013:142). The gap identified in the research is that city administrations are not ready or sufficiently resourced to take advantage of digitalisation and the fourth industrial revolution. Therefore, a multi-governance approach in conjunction with the King IV corporate governance framework must be explored by the eThekwini Municipality in the development of a municipal governance strategy in order to address the implications of the fourth industrial revolution. This will also help to improve intergovernmental obligations, as well as review institutional capacity, financial and other resources and skills for digitalisation.

Leadership and governance are essential for municipal organisations to strategically use technological tools and digitalisation, not only to communicate with the public but also to invite the public to become part of the decisionmaking within the organisation. Multilevel governance collaborations must be initiated, in order to ensure that the fourth industrial revolution is advanced through the collaborated efforts of all sectors of government, rather than by silo organisations.

These recommendations provide government with the tools to ensure that there is integration in the alignment of processes within the organisations and prevent formation of silos. An amalgamated approach to the fourth industrial revolution also directs energy and momentum to any effort that this made, securing faster access to international economic markets. The recommendations of the research could potentially assist other municipalities in improving the municipal governance frameworks to address the fourth industrial revolution.

Furthermore, unless political and administrative leadership support is in place to embed the governance frameworks within municipalities, the fourth industrial revolution will be a far-off vision.

\section{Acknowledgement}

The author, Nirmala Govender, thanks Prof. P.S. Reddy (doctoral promoter) for the guidance and Dr P. Kariuki for reviewing the article.

\section{Competing interests}

The authors declare that they have no financial or personal relationships that may have inappropriately influenced them in writing this article.

\section{Authors' contributions}

All authors contributed equally to this work.

\section{Funding information}

This research received no specific grant from any funding agency in the public, commercial or not-for-profit sectors.

\section{Data availability statement}

Data sharing is not applicable to this article as no new data were created or analysed in this study. 


\section{Disclaimer}

The views and opinions expressed in this article are those of the authors and do not necessarily reflect the official policy or position of any affiliated agency of the authors.

\section{References}

Aranguren, M.J., 2018, Multilevel governance and involvement of small enterprises in the RIS3 of Basque country, Orkestra - Basque Institute of Competiveness and Deusto Business School, RIS3 Vivo Policy Brief 2, pp. 1-14, Duesto Foundation, Universidad de Deusto, Orkestra.

Bacon-Shone, J., 2015, Introduction to quantitative research methods, pp. 15-54, Graduate School, The University of Hong Kong, Hong Kong.

Bryman, A., 2012, Social Research Methods, 4th edn., Oxford University Press, New York.

Butler, M., 2018, The implications of having an industrial revolution in one generation, viewed 20 March 2019, from https://www.fin24.com/Finweek/ Featured/the-implications-of-having-an-industrial-revolution-in-one-generation20180409.

City of Cape Town, 2017, Five-year integrated development plan - July 2017 - June 2022, p. 63, City of Cape Town, Cape Town.

Copping, P., Eskelinen, J., Figueredo, K., Fisher, M. \& Frost, L., 2018, The 4th industria revolution and the municipal CEO, 1st edn., ETSI White Paper No. 26, European Telecommunications Standards Institute (ETSI), Sophia Annapolis.

Daniel, E., 2016, 'The usefulness of qualitative and quantitative approaches and methods in researching problem-solving ability in science education curriculum', Journal of Education and Practice 7(15), 91-100.

Denhardt, J.V. \& Denhardt, R.B., 2007, The new public service: Serving not steering, p. 139, M.E. Sharpe Inc., New York.

Dunleavy, P., Margetts, H., Bastow, S. \& Tinkler, J., 2006, 'New Public Management Is Dead - Long Live Digital-Era Governance', Journal of Public Administration Research and Theory, 16(3), 467-494. https://doi.org/10.1093/jopart/mui057

eThekwini Municipality, 2015, Policy - Corporate governance of information, communication and technology for eThekwini municipality, eThekwini Municipality Policy, eThekwini Municipality, eThekwini, Durban.

eThekwini Municipality, 2018a, About Ethekwini municipality, viewed 13 June 2019, from http://www.durban.gov.za/Discover_Durban/Pages/AboutEM.aspx.

eThekwini Municipality, 2018b, Ethekwini Municipality Annual Report 2017-2018, pp. 31-50, eThekwini Municipality, eThekwini, Durban.

eThekwini Municipality, 2018c, Ethekwini municipality integrated development plan - 5-year plan 2017-2018 to 2012-2022: 2018/19 review, pp. 109-256, eThekwin Municipality, eThekwini, Durban.

Harvey, R., 2017, The 'Fourth industrial revolution': Potential and risks for Africa, viewed 14 April 2019, from http://www.naci.org.za/nstiip/index.php/analyticalcontributions/technological-progress/40-the-\% $\% 27$ fourth-industrial-revolution $\% 27$ potential-and-risks-for-africa.

Heeks, R. \& Bailur, S., 2007, 'Analyzing e-government research: Perspectives, philosophies, theories, methods, and practice', Government Information Quarterly 24(2), 243-265. https://doi.org/10.1016/j.giq.2006.06.005

Holdsworth, T., 2018, 'Multi-channel delivery and the modernisation of government services', Service Delivery Review 11(3), 17-19.

Isandla Institute, 2012, 'The shape of things to come: Towards a more accountable, responsive and people-centred local government?', in The Politics of Local Governance, Isandla Institute.

Innolytics, 2019, What is digitalization, viewed 20 August 2019, from https:// innolytics-innovation.com/what-is-digitalization/.

Institute of Directors South Africa (IODSA), 2016, King IV report on corporate governance for South Africa 2016, IODSA, Johannesburg.

Jagannath University, 2019, Comparison between public governance and corporate governance, viewed 20 August 2019, from https://www.coursehero.com/file/ p644ccd/Comparison-between-Public-governance-and-Corporate-GovernancePublic-Governance/.

Johnson, B. \& Christensen, L., 2012, Educational research, qualitative, quantitative and mixed approach, 4th edn., Sage, Los Angeles, CA.

Lamb, H., 1995, Our Global Neighborhood: Report of the Commission on Global Governance, A Summary Analysis, viewed n.d., from https://www. bibliotecapleyades.net/sociopolitica/sociopol_globalization05.htm.

Mbecke, P., 2014, 'Corporate municipal governance for effective and efficient public service delivery in South Africa', Journal of Governance and Regulation 3(4), 98-106. https://doi.org/10.22495/jgr_v3_i4_c1_p2

McGinnis, D., 2018, What is the fourth industrial revolution?, viewed 20 August 2019, from https://www.salesforce.com/blog/2018/12/what-is-the-fourth-industrialrevolution-4IR.html.

Mulili, B.M. \& Wong, P., 2011, 'Corporate governance practices in developing countries: The case for Kenya', International Journal of Business Administration 2(1), 14.
Municipal Demarcation Board (MDB), 2017, Municipal boundary demarcation board, MDB, Centurion.

Mzekandaba, S., 2018, 'SA's e-government strategy showing progress', Service Delivery Review 11(3), 14.

Ndaliso, C., 2019, eThekwini council's R600m billing system headache, viewed 13 June 2019, from https://www.iol.co.za/dailynews/news/kwazulu-natal/ ethekwini-councils-r600m-billing-system-headache-20939380.

O'Callaghan, G., 2018, Digitalisation - driving the fourth industrial revolution, viewed 20 August 2019, from https://www.techcentral.ie/digitalisation-driving-fourthindustrial-revolution/.

Organisation for Economic Co-operation and Development (OECD), 2016, OECD: Digital government strategies for transforming public services in welfare areas, Organisation for Economic Co-operation and Development, Paris.

Osborne, S.P., Radnor, Z. \& Nasi, G., 2013, 'A new theory for public management? Toward a (public) service-dominant approach', The American Review of Public Administration 43(2), 135-158. https://doi.org/10.1177/0275074012466935

Price, N.J., 2018, What constitutes good governance, viewed 20 August 2019, from https://insights.diligent.com/corporate-governance/what-constitutes-goodgovernance/.

PricewaterhouseCoopers (PWC), 2018, Fourth industrial revolution for the Earth Harnessing artificial intelligence for the Earth, p. 1, PricewaterhouseCoopers, London.

PricewaterhouseCoopers (PWC) \& Institute of Directors South Africa (IODSA), 2010, Local government and King III: Public sector working group position paper 2, p. 1, PWC and IODSA, Johannesburg.

Republic of South Africa (RSA), 2014. Twenty-year review: South Africa - 1994 to 2014 - Background paper - Local government, Department of Planning, Monitoring and Evaluation, Pretoria.

Republic of South Africa (RSA), 2018a, The digital industrial revolution, Department of Trade and Industry, viewed 20 March 2019, from http://www.dti.gov.za/ industrial_development/fipt.jsp.

Republic of South Africa (RSA), 2018b, General notice: Invitation to nominate candidates for the presidential commission on fourth industrial revolution, Department of Telecommunications and Postal Services, Notice 764 of 2018, Government Gazette, Pretoria.

Reddy, P.S., 2016, 'The politics of service delivery in South Africa: The government sphere in context', The Journal for Transdisciplinary Research in Southern Africa 12(1), 1-8. https://doi.org/10.4102/td.v12i1.337

Roberge, I., 2018, 'The fourth industrial revolution and the government of the future: Taking stock of the future of government', Service Delivery Review 11(3), 8-10.

Robinson, M., 2015, From the old public administration to the new public service Implications for public sector reform in developing countries, UNDP Global Centre for Public Service Excellence, Singapore.

Schwab, K., 2016, The fourth industrial revolution: What it means, how to respond viewed 20 August 2019, from https://www.weforum.org/agenda/2016/01/thefourth-industrial-revolution-what-it-means-and-how-to-respond/,WEF.

Shaikh, N., 2018, Millions spent on consultants to run eThekwini's billing system viewed 13 June 2019, from https://www.iol.co.za/sunday-tribune/news/millionsspent-on-consultants-to-run-ethekwinis-billing-system-15407744.

Taylor, Z., 2016, Good governance at the local level: Meaning and measurement, University of Toronto, Toronto.

Tshabalala, S., 2019, South Africa in the fourth industrial revolution: A new opportunity to create more jobs and a better society, viewed 20 March 2019, from https:// corporateandinvestment.standardbank.com/CIB/About-us/Insights-Hub/SouthAfrica-in-the-fourth-industrial-revolution:--A-new-opportunity-to-create-moreAfrica-in-the-fourth-industri
jobs-and-a-better-society.

United Nations (UN), 2018, The Sustainable Development Goals Report-2018, United Nations, New York, NY.

Van der Merwe, M., 2019, Tito and the fourth industrial revolution, viewed 13 April 2019, from https://www.fin24.com/Budget/tito-and-the-fourth-industrialrevolution-20190227.

West, K., 2018, Three truths for gearing up to the fourth industrial revolution, viewed 20 March 2019, from https://www.fin24.com/Opinion/three-truths-for-gearingup-to-the-fourth-industrial-revolution-20180301.

World Bank, 2018, Doing business in South Africa 2018, World Bank, Washington, DC.

World Economic Forum (WEF), 2016, A call for agile governance principles, pp. 1-2 viewed 20 August 2019, from http://www3.weforum.org/docs/IP/2016/ICT/ Agile_Governance_Summary.pdf.

World Economic Forum (WEF), 2017, The Africa competitiveness report 2017, pp. 22, World Economic Forum, Geneva.

World Economic Forum (WEF), 2018, Agile governance - Reimaging policy-making in the fourth industrial revolution, p. 5-9, White Paper, World Economic Forum, Geneva.

World Economic Forum (WEF), 2019, The fourth industrial revolution by Klaus Schwab, viewed 13 June 2019, from https://www.weforum.org/about/the-fourth-industrialrevolution-by-klaus-schwab.

Yildiz, M., 2007, 'E-government Research: Reviewing the Literature, Limitations, and Ways Forward', Government Information Quarterly, 24(3), 646-665. https://doi. org/10.1016/j.giq.2007.01.002 